\title{
Los cuerpos de la violencia y su representación en el arte ${ }^{1}$
}

\section{Ileana Diéguez ${ }^{2}$}

\section{Resumen:}

La realidad del cuerpo hoy indica la emergencia de síntomas y patologías sociales que de distintas maneras contaminan las prácticas del pensamiento y del arte. En particular, el arte mexicano de las últimas décadas está elaborando iconografías en las que late el impacto traumático por el despedazamiento emblemático a que ha sido sometido el cuerpo desde hace más de siete años. El arte ha sido permeado de un registro esencialmente alegórico y sacrificial, pero también de un registro documental. Ante estas configuraciones visuales no he dejado de preguntarme: ¿Cómo se ha conmocionado o contaminado una práctica como la escénica que durante siglos ha hecho tributo y monumento al cuerpo? ¿Cómo dialoga el arte escénico con este estado del cuerpo? ¿Cómo se ha contaminado la práctica teatral con esta rotura y disolución corporal?

\begin{abstract}
:
The reality of the body nowadays indicates the emergency of social symptoms and pathologies that contaminate practices of thinking and of art. Art has been permeated by an allegorical and sacrificial register, but also documental. Before these visual configurations I keep asking myself: how has a practice like the scenic, that has paid tribute to the body for centuries, been contaminated? How does the scenic art dialogue with this state of the body? How has the theatrical practice been contaminated with this rupture and dissolution of the body?
\end{abstract}

Keywords: Body, Violence, Performing Arts

Palabras Clave: Cuerpo, Violencia, Arte

Escénico

$1 \quad$ Este texto hace parte de las reflexiones planteadas en Cuerpos sin duelo. Iconografías y teatralidades del dolor (Córdoba-Argentina: DocumentA/Escénicas, 2013), de esta autora.

2 Profesora investigadora de la Universidad Autónoma Metropolitana (UAM-Cuajimalpa). 
La realidad del cuerpo hoy indica la emergencia de síntomas y patologías sociales que de distintas maneras contaminan las prácticas del pensamiento y del arte. En particular, el arte mexicano de las últimas décadas está elaborando iconografías en las que late el impacto traumático por el despedazamiento emblemático a que ha sido sometido el cuerpo desde hace más de siete años. $\mathrm{El}$ arte ha sido permeado de un registro esencialmente alegórico y sacrificial, pero también de un registro documental. Ante estas configuraciones visuales no he dejado de preguntarme: ¿Cómo se ha conmocionado o contaminado una práctica como la escénica que durante siglos ha hecho tributo y monumento al cuerpo? ¿Cómo dialoga el arte escénico con este estado del cuerpo? ¿Cómo se ha contaminado la práctica teatral con esta rotura y disolución corporal?

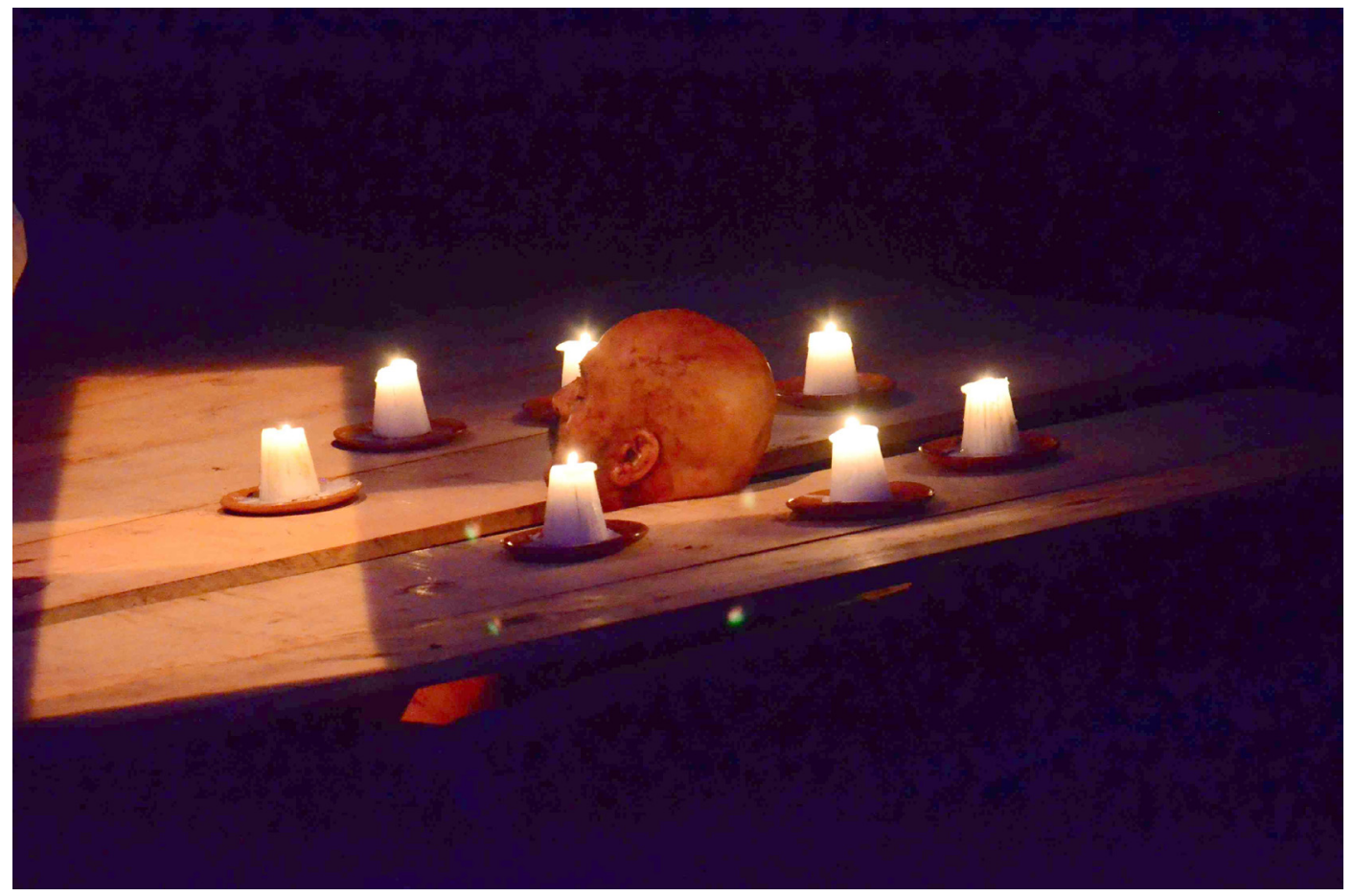

Imagen 1

Bacantes. Para terminar con el juicio de Dios, La Rendija, Yucatán, dirección Raquel Araújo. Foro Sor Juana Inés de la Cruz, UNAM, junio 2013. Fotografía Juan Enrique González.

¿Cómo se precipitan esas preguntas en el universo tejido por el grupo La Rendija bajo la aguda mirada de Raquel Araújo? ¿Qué nuevos dioses determinan el juicio y la producción de un mundo de restos, de carnalidades sin cuerpo, de amnesias y de inercias? Bacantes. Para terminar con el juicio de Dios ${ }^{1}$, no es la puesta en escena de un texto dramático o de una historia griega. Es un Penteo contemporáneo. El relato visual, carnal y verbal que allí tiene lugar nos atañe demasiado. La historia cotidiana de estos tiempos. Más que una escena de personajes es una escena de situaciones. De evocaciones iconográficas que nos connotan y nos convocan. De pequeños rituales en los que siempre se sacrifica el cuerpo. La fiesta de la carne, la bacanal de los cuerpos en restos. Cuerpos en duelo, en combate, en agonía y en sacrificio. Ofrenda de restos. De ropas sin cuerpos, de vísceras, de flujos corporales, de cabezas, de Pietá contemporánea. Pienso que en la escena mexicana, como ninguna otra obra escénica, Bacantes ha explorado el estado límite de los cuerpos y ha puesto ante nuestros ojos la trágica iconografía de estos tiempos. 


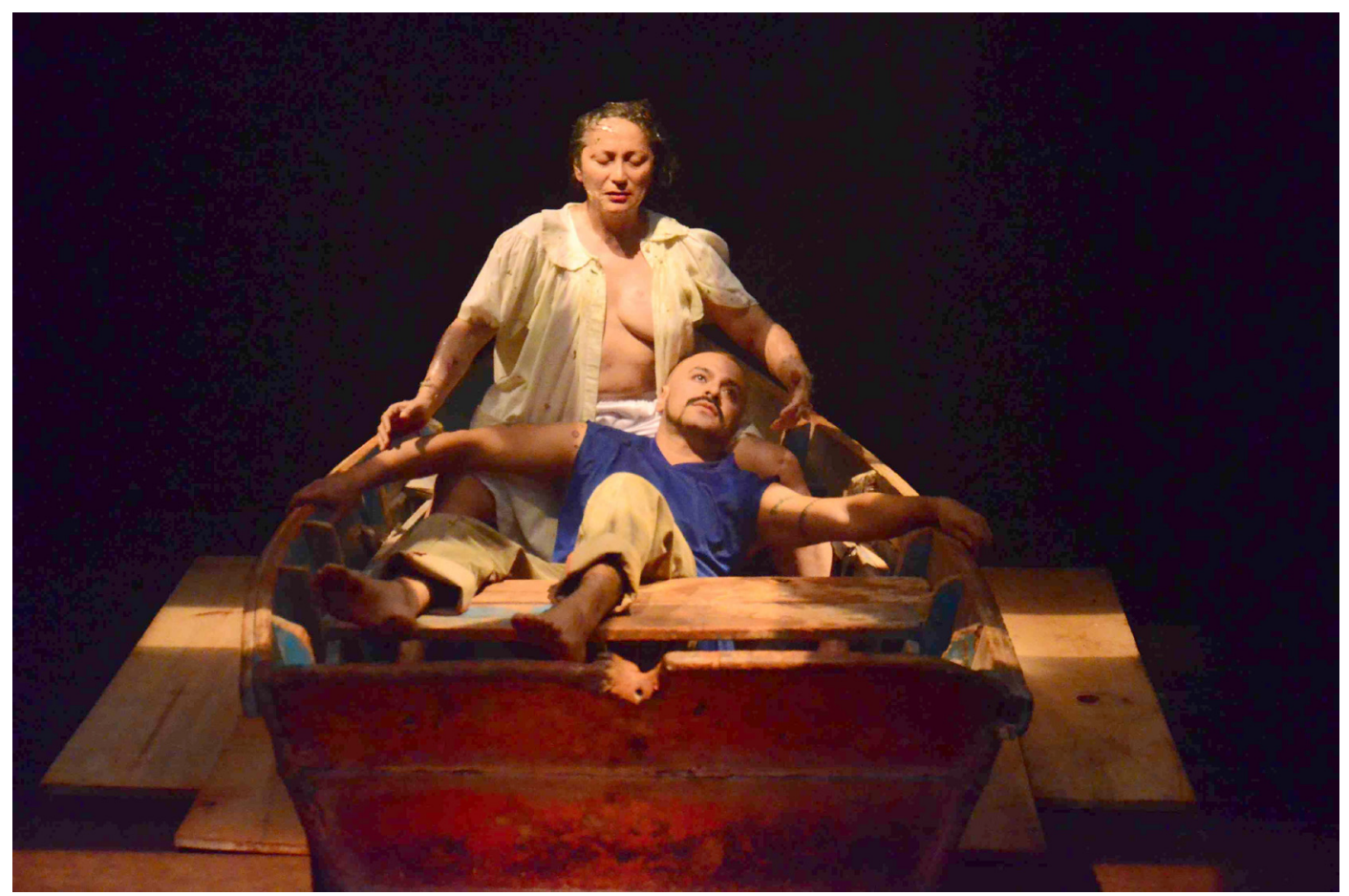

Imagen 2

Bacantes. Para terminar con el juicio de Dios, La Rendija, Yucatán. Foro Sor Juana Inés de la Cruz, UNAM, junio 2013. Fotografía Juan Enrique González.

Desde hace más de siete años, y a partir de la guerra declarada a los cárteles de la droga por el entonces Presidente de México, Felipe Calderón (2006-2012), los amontonamientos de cuerpos desmembrados y acéfalos, el vergonzoso crecimiento de cifras sobre las desapariciones y apariciones parciales de restos corporales, los descubrimientos de fosas comunes, la acumulación creciente de NNs (nomen nescio, sin nombre), han acaparado la nueva representación de nuestra corporalidad, en una especie de cínica fantasía anatómica.

Los escenarios donde el cuerpo se expone como el principal objeto de martirio y trofeo, tiene un alto carácter representacional. La antropología colombiana ha aportado importantes estudios como los de Elsa Blair y María Victoria Uribe en torno a las teatralizaciones del exceso y las maneras de ejecutar y representar las intervenciones violentas sobre el cuerpo. Si la figura del desaparecido inauguró las terminologías de las guerras sucias y las dictaduras latinoamericanas en los años setenta, hace varios años la figura del desmembrado se ha impuesto desde la violencia colombiana y ha penetrado los actuales escenarios mexicanos. El propósito no es sólo matar sino ejecutar un ritual de exterminio que sirva a otros como evidencia aleccionadora. Como ha dicho la antropóloga colombiana María Victoria Uribe, se trata de matar, rematar y contramatar.

Desde la experiencia de la violencia extrema desatada en México, he ensayado la posibilidad de aproximar las nociones de teatralidad y performatividad a los despliegues y representaciones de poder que se libran entre los distintos grupos por el control de los territorios y la venta de estupefacientes. Los cuerpos expuestos en los espacios públicos de México, como también sucedió en Colombia, son sometidos a lo que Foucault planteó como una política punitiva del cuerpo (Foucault, 1976, pp. 98-99): son la expresión de un castigo que toma la forma de un recordatorio, de un mensaje corporal, de un memento mori. Los fragmentos corporales lanzados al espacio público y dispuestos de manera que comuniquen un relato, una idea, un mensaje, son el punto de partida para una reflexión 
que busca abordar estas representaciones como escenificaciones, performatividades o teatralidades de la violencia. Estos acontecimientos, expuestos a la mirada de otros devienen escenas en las que se expresa un 'necropoder' ${ }^{2}$ La realidad de esas escenas ha sido el punto de partida para proponerme abordar estas representaciones como 'necroteatro'. Este necroteatro está vinculado al propósito de poner ante los ojos la evidencia espectacular del sufrimiento, la escena aterradora de un discurso de poder que aniquila el cuerpo humano en vida y post mortem con propósitos aleccionadores. Las escenificaciones de la violencia alcanzan su punto más álgido en los cuerpos, atravesados por las relaciones de poder. Los cuerpos de la violencia serán siempre cuerpos irreversiblemente dislocados. Las imágenes producidas en estas circunstancias constituyen el emblema más poderoso para el ejercicio del miedo.

Los rituales de sufrimiento, cualquiera que sea el fin, producen marcas y transforman los cuerpos: "el cuerpo es una memoria", afirma Pierre Clastres $(1978,160)$, quien ha reflexionado sobre la situación de los cuerpos marcados en los rituales de iniciación guayaquí. A esos rituales Clastres los ha considerado como una "pedagogía de afirmación" (161) que recuerda a sus miembros los vínculos de pertenencia. La ley de la sociedad queda inscrita en sus cuerpos ${ }^{3}$. La memoria de la ley es ejercida como escritura corporal. Tal y como sucede con los cuerpos bajo el poder soberano que decide quién vive o quien muere (Mbembe, 2006, 30). Los cuerpos hablan a través de la sevicia escritural ejercida sobre ellos. La ley decide el tipo de escritura y de superficie en la cual se imprimirá.

Los cortes que transforman el cuerpo a partir del cercenamiento de las partes y la redistribución de las mismas, funcionan como una dislocación del ordenamiento natural del cuerpo, creando una especie de anomalía sobre la que se constituye un nuevo sistema de significaciones. Este otro cuerpo implica una alteración de la gramática corporal convencional. Es un cuerpo desmontado. De manera distinta, el cuerpo descuartizado, reducido a "un montón de carne" implica una aniquilación de todo orden corporal, es apenas un amontonamiento de pedazos, vestigios, ruinas, de lo que fue un cuerpo. Cuando los cuerpos son desaparecidos mediante procesos químicos de disolución, o por sumergimiento en las aguas, o porque se reducen a cenizas por la acción del fuego, lo que se ejecuta o se persigue es la borradura de todo vestigio, la invisibilización total del cuerpo y su muerte. Todas las intervenciones sobre el cuerpo, matándolo por segunda o tercera vez, mutilando o desfigurándolo, pervirtiendo o desapareciendo la identidad de las víctimas, buscan exponer su degradación a la vista de otros y darle a ello un sentido, utilizando la disposición de esos fragmentos para hacerlos hablar y producir un mensaje corporal que expanda el terror.

Según el criminólogo Daniel Cunjama, las torturas y cortes que en México se aplican al cuerpo, evidencian códigos que determinan los tipos de mensajes enviados por los cárteles: “A los soplones se les corta o se les saca la lengua. A quien roba le cortan los dedos. A los testigos incómodos les sacan los ojos o les cortan las orejas. Detrás de cada tortura hay un mensaje" (Cunjama cit. en Vera, 5 junio $2011,11)$. Las partes del cuerpo intervenidas, torturadas o mutiladas, indican el acto o la acción por el cual se le está castigando y asesinando.

Desde hace varios años, el arte colombiano, ha ido produciendo alegorías de estos estados corporales. En 1997, el artista visual Juan Manuel Echavarría fotografía huesos humanos dispuestos en formas florales que evocaban las ilustraciones de expediciones botánicas, en particular la Real

$2 \quad$ El término "necropoder" ha sido introducido por Achille Mbembe (2006), quien parte de las nociones de soberanía y biopoder desarrolladas por Michel Foucault para para repensar el actual despliegue de los poderes de la muerte, utilizando la noción de necropoder para indicar la manifestación específica del terror actual.

3 Veena Das considera muy claras las conexiones genealógicas entre las formulaciones de Clastres sobre la tortura en las prácticas de iniciación y las formulaciones de Durkheim sobre las dolorosas inscripciones totémicas en el cuerpo $(2008,415)$. 
Expedición Botánica del siglo XVIII encabezada por José Celestino Mutis. La serie creada, Corte de florero, es una alegórica aproximación a la barbarie y al terror impuesto a los cuerpos. Desde un extrañado lenguaje, la flora necrológica allí expuesta era una alegoría de los desmembramientos corporales. El nombre de esta serie, Corte de florero, es también el nombre de una de las mutilaciones realizadas a los cuerpos durante el período de la Violencia partidista en Colombia. Se trata de una serie fotográfica que primero tuvo que ser montada, escenificada, para poder ser registrada. Los objetos fotografiados no son flores naturales sino simulan ser arreglos florales realizados a partir de huesos humanos obtenidos por medio de contactos médicos.

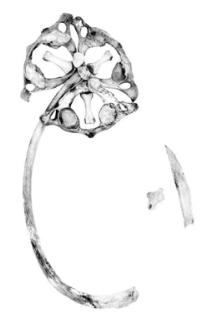

Imagen 3

Dionaea Severa, de la serie Corte de Florero (1997), de Juan Manuel Echavarría. Archivo Juan Manuel Echavarría, cortesía del artista.

Otros artistas han explorado acercamientos alegóricos a los cortes de la Violencia en Colombia. Caudillo con lengua, 2000-2007, de Rosemberg Sandoval, es una acción realizada en una morgue, registrada en fotografía y video, y en la cual del artista posa vestido de negro con la "lengua de un cadáver humano anónimo" enganchada a su cuello. En esta acción se configura una evidente alusión al llamado "corte de corbata" en el cual la lengua era retrotraída y mostrada a través de un agujero por debajo del mentón. 


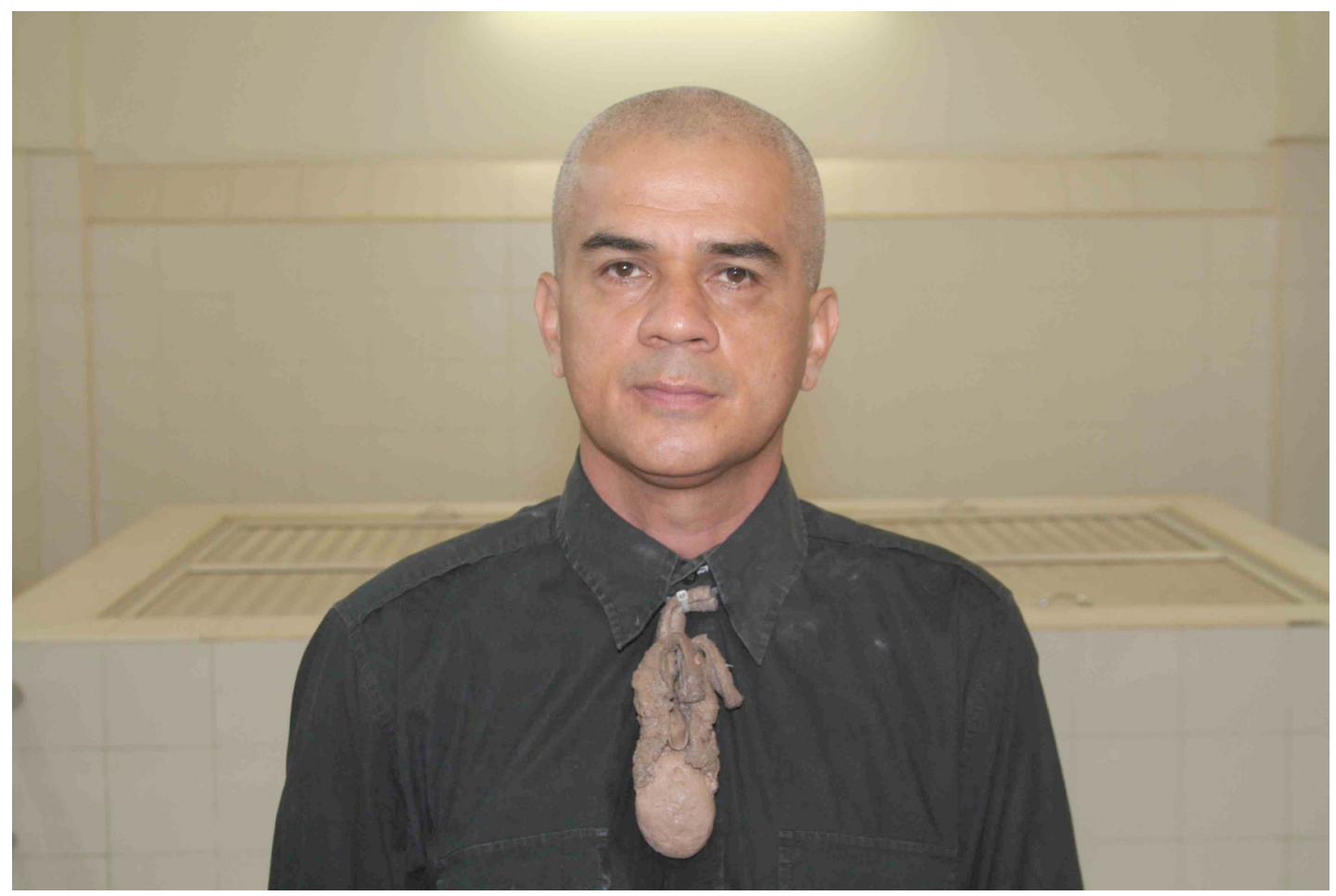

Imagen 4

Caudillo (con lengua), 2000-2007, performance de Rosemberg Sandoval, Cali, Colombia. Fotografías de José Kattan y Oscar Monsalve. Imagen tomada de la página con el consentimiento del artista:

\section{http://www.rosembergsandoval.com/imagenes/popups/caudillo_con_lengua1.htm}

Los cuerpos de la violencia en México se han contado por el número de cabezas producidas, dispuestas, instaladas en distintos espacios públicos, como si se propusieran reproducir una nueva versión de naturalezas muertas, una puesta en escena de cabezas parlantes. Cuando se encuentra la cabeza se sabe que habrá que encontrar el resto del cuerpo. La práctica de contar el cuerpo por la cabeza, u otra parte que lo represente, ha sido una usanza cultural a través de los tiempos. La cabeza en su decir sinecdóquico, la parte que vale por el todo y que en varias culturas alcanza una dimensión de símbolo ascensional por su verticalidad, si tenemos en cuenta la reflexión de Gilbert Durand: "los esquemas verticalizantes desembocan en el plano del macrocosmos social en los arquetipos monárquicos, como en el macrocosmos natural desembocan en la valorización del cielo y las cimas" $(2004,146)$. Para los pueblos que nos precedieron, la cabeza es el centro y principio de la vida, contenedora de la fuerza física, psíquica y espiritual. Y lo sigue siendo en todos los tiempos. La práctica de contar el cuerpo por la cabeza y de ritualizar como trofeo esta parte corporal, ha generado otra serie de prácticas antiguas y contemporáneas.

El efecto aterrorizante de las cabezas cercenadas durante el imperio de la guillotina francesa -se estima que fueron veinte mil los cuerpos acéfalos producidos bajo el Terror revolucionariotrascendió como un icono reiteradamente explorado en los dibujos y pinturas de los artistas franceses: Eugéne Delacroix: Tête de damnés, 1819-22; Théodore Géricault: Quatre études de la tête d'un guillotiné, 1818-1820; Odilon Redon: Tête de martyr, 1877; entre muchos otros.

La fragmentación y mutilación corporal, como acto de descomposición y degradación 
humana, ha sido siempre un recurso político. En pleno siglo XX, la exposición de cabezas cortadas ha sido utilizada -como hasta hoy-, con fines aleccionadores. La guerra librada contra el Cangaço, y en particular contra el Rei do Cangaço, el mítico Lampião, en el Sertão del Nordeste brasileño, fue sellada con la exhibición de once cabezas, entre ellas las del propio Lampião y su compañera Maria Bonita, junto a los típicos sombreros, vestidos, alforjas, monturas, cuchillos, rifles, y hasta las máquinas de coser con las que las mujeres cosían la ropa, a modo de escarmiento para quienes desafiaran a la autoridad. A la manera de un altar de cabezas y vestigios, la imagen devino una perturbadora instalación, fotografiada el 28 de julio de 1938.

Al finalizar los años noventa, el artista norteamericano Joel-Peter Witkin fotografió en una morgue de la Ciudad de México la cabeza de un hombre que había muerto en un accidente. Cabeza de hombre (1990) es una imagen que ha devenido profética. Una imagen-fantasma que devendría imagen-síntoma cuando varios años después perturbaría nuestra percepción bajo en el curso de ciertos acontecimientos. Una imagen anacrónica que desde un pasado no muy lejano -desde hace un poco más de dos décadas- retorna para hacer visible el recargamiento simbólico de los iconos.

Didi-Huberman ha echado andar entre nosotros las metáforas teóricas de la "imagenfantasma" y la "imagen-síntoma". Configurada a partir del Nachlebem o supervivencia de Aby Warburg, la noción de "imagen-fantasma" señala las supervivencias, latencias y reapariciones que habitan las imágenes. Por lo que esas imágenes anuncian, a modo de síntoma, para reaparecer en otros tiempos, devienen "proféticas".

En la imagen de Witkin se tejen los tiempos. Ella es la supervivencia de un icono que apareció a destiempo, a manera de un síntoma, de una terrible profecía que anunciaba el advenimiento de una tragedia. Pero a la vez, en esa imagen superviven las iconografías martirológicas del Barroco. Para hacer la foto, Witkin colocó la cabeza del hombre sobre un plato. Aunque los relatos que están detrás de las imágenes son totalmente diferentes, la imagen realizada por Witkin visualmente evoca la Cabeza del Bautista (1646) de José de Ribera.

En un juego de anacronías, esta imagen reúne varias temporalidades: desde las iconografías sacrificiales prehispánicas registradas en mitos y códices que exponen la dimensión iconofílica de una cultura, pasando por los martirios barrocos que hicieron del martirio y los fragmentos corporales el objeto de las representaciones pedagógicas y piadosas; hasta prefigurar esa imagen-fantasma por la que se cuentan los cuerpos y que ha devenido una neobarroca alegoría del miedo, dada la insistencia de su multiplicación y la forma espectacular de sus reiteradas apariciones, especialmente desde aquellas cabezas lanzadas sobre la pista de baile en un centro nocturno de Uruapan, Michoacán, en septiembre de 2006, a modo de escena iniciática de una guerra que ha tenido su réplica más terrible en las cabezas comunes de miles de personas. Cabeza de hombre es hoy una imagen que desde las iconografías reservadas a los espacios del arte nos perturba y nos llena de preguntas respecto a su fatídica supervivencia. Su cualidad fantasmal -más allá de la que tiene toda fotografía- se amplifica en las actuales fotografías que difunden la imagen de cabezas de hombres, de los miles de restos cadavéricos que desde los espacios públicos evidencian, rotundamente, el estado de las cosas.

El fantasma del cuerpo desmontado, descabezado, corroe, contamina, atormenta los imaginarios y escenas contemporáneas. La cabeza, ese fragmento altamente emblemático, puede aparecer en cualquier sitio, adivinarse en cualquier bulto, aparecer instalada en los espacios públicos. El fantasma del cuerpo roto permea hoy las prácticas artísticas. 


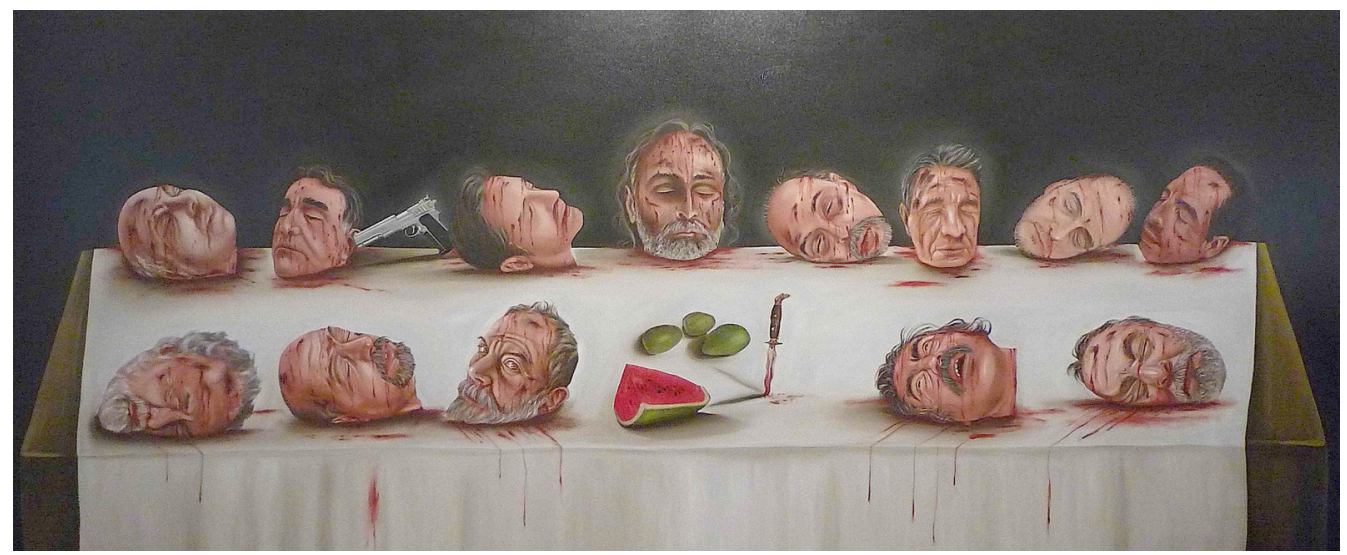

Imagen 5

La Última Cena Mexicana, de Gustavo Monroy, óleo sobre tela, 2010. Cortesía del artista.

Pero junto a estas formas de intervención y transformación de los cuerpos, en México ha ido emergiendo otra figura fantasmal, por la carga mortuoria que ella ha implicado. Se trata de la imagen del "encobijado", del muerto envuelto en cobijas, ésas que comúnmente se usan para protegerse del frío y que ahora cumplen la función de improvisadas mortajas.

La artista sinaloense (México) Rosa Marìa Robles ha creado una serie fotográfica donde el elemento reiterado es la cobija, esa mortaja mexicana que envuelve los cuerpos y que en la obra de esta artista es una mancha dolorosa de la carnicería humana que determina la vida y el arte de estos tiempos. En la obra de Robles, las cobijas aparecieron por primera vez en Alfombra Roja, instalación realizada en el 2007 en el Museo de Arte de Sinaloa. En ella se integraron ocho cobijas que aún exhibían las manchas de sangre de las víctimas. Colocadas a manera de alfombra que parodiaba la red carpet hollywoodense, la obra invitaba a los espectadores a caminar sobre la sangre derramada en México, a la vez que los confrontaba ante un enorme espejo.

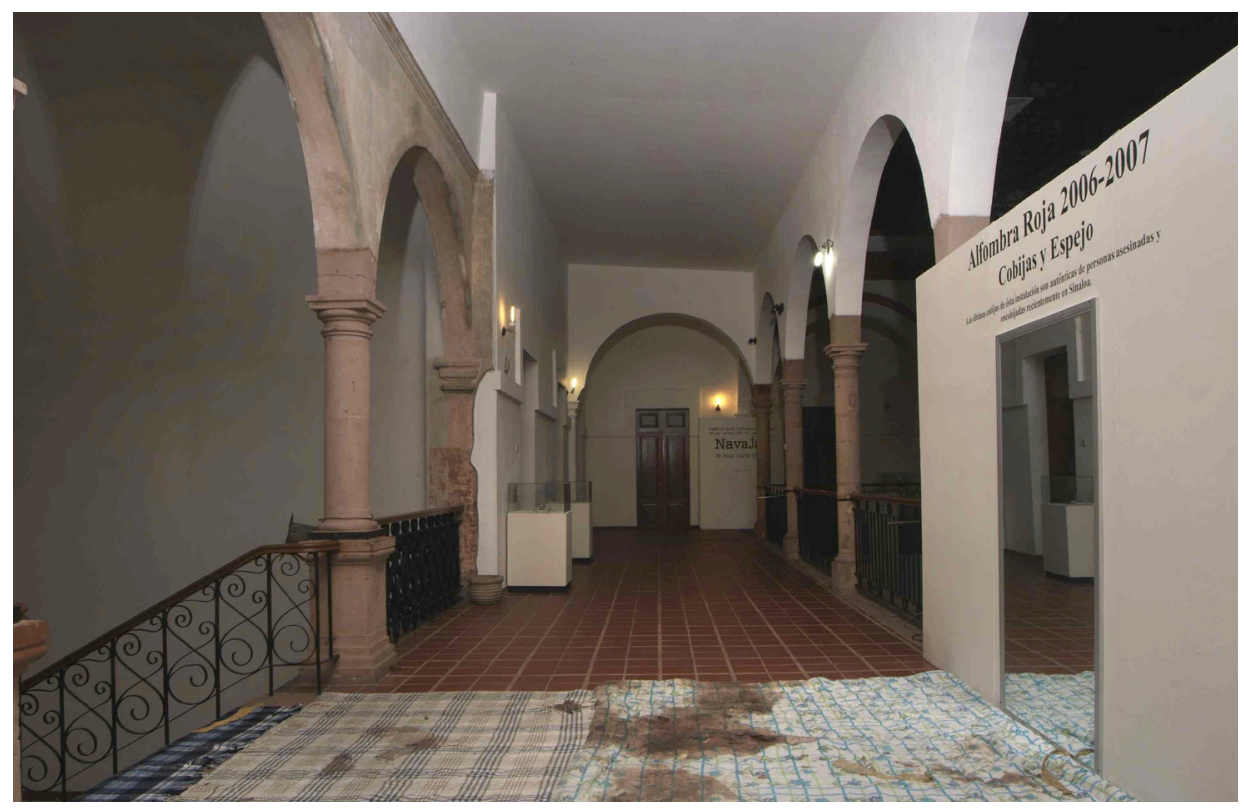

Imagen 6

Alfombra Roja, en Navajas, de Rosa María Robles. Museo de Arte de Sinaloa, Culiacán, 2007. Fotografía de Jesús García. Cortesía de la artista. 
Es recurrente en el arte contemporáneo la incorporación de objetos diversos que han pertenecido a víctimas de la violencia y que exponen los restos metonímicos de la realidad última de los cuerpos. En determinadas circunstancias, prohibir el uso de estos contaminados objetos deviene alegato político en nombre de un supuesto estado moral. Y esto fue lo que sucedió cuando la obra fue intervenida por la Procuraduría de Justicia del Estado de Sinaloa, imponiendo la retirada de aquellas cobijas. Pero lo que pretendía ser controlado dio lugar a nuevos gestos, nuevos mantos y texturas fantasmales. Pervirtiendo la presencia con su aparición fantasmática, Rosa María Robles echó mano a la estrategia performativa y al dispositivo fotográfico. Una nueva Alfombra Roja nació como resultado de su accionar performativo, manchando con su propia sangre nuevas cobijas. Aquel gesto de censura también impulsó la serie fotográfica La rebelión de los iconos, en la cual la artista se hace fotografiar parodiando paradigmáticas imágenes de la cultura y de la historia del arte. Así nacieron sus piezas El Ángel de la Independencia, La Estatua de la Libertad, El Cristo de La Habana, Renacimiento, La Maja desnuda, Almuerzo sobre la hierba, La Piedad. Toda la serie está mortalmente signada por la cobija.

Si la fotografía nos instala en un teatro de la muerte -como ha dicho Roland Barthes- donde predomina el orden espectral, las imágenes creadas por Robles acentúan un doble régimen fantasmal. La cobija con su inevitable espectralidad, siempre está en lugar de los cuerpos. Los escenarios están extrañados por esas apariciones que exhiben su poder sintomático. Lo real -en los objetos contaminados, en las imágenes fotográficas de los cuerpos abiertos- interrumpe el curso normal de la representación visual y crea la aparición de los síntomas, lo que Didi-Huberman ha nombrado como la paradoja visual de la aparición $(2006,63)$.

La relación entre imagen y síntoma la extrae Didi-Huberman de los textos de Freud, de las reflexiones de éste en torno al comportamiento histérico y a la percepción teatral de la histeria. A partir del análisis de las escenas de histéricas estudiadas por Freud (apoyadas en las fotografías de Charcot en la Salpêtrière) comenzó a construirse la teoría sobre el papel de la imaginación y de las imágenes en la expresión del síntoma. Al ser percibido como "reproducción de escenas", el síntoma histérico era comparable a un cuadro pictórico (Didi-Huberman, 2012, 55). Fue allí donde comenzó a construirse la teoría sobre el papel de la imaginación y de las imágenes en la expresión del síntoma, reflexión teórica que también Aby Warburg abordó y enriqueció. Al trasladar a los territorios de la imagen la noción de síntoma, Didi-Huberman propone: “ ¿El síntoma no es la fisura en los signos, la pizca de sinsentido y de no saber de dónde un conocimiento puede extraer su momento decisivo?" $(2012,24)$. El síntoma ha sido problematizado como una interrupción en el saber, un "signo secreto" que agujerea lo supuestamente conocido. La imagen siempre se ha concebido como una forma de conocimiento; su vínculo con el síntoma la coloca entonces en una situación más complementaria que opuesta al pensarse el síntoma como "una interrupción en el saber" (25). Síntoma y conocimiento como dos caminos que conviven en la imagen.

¿Cómo trasladar este pensamiento de los síntomas como interrupciones en lo conocido a una producción artística mexicana en un contexto de reforzada violencia sobre los cuerpos? En las fotografías de la serie La rebelión de los iconos, la artista sinaloense reitera un elemento que interrumpe cualquier supuesto saber sobre las imágenes, pues ellas son imágenes que viajan desde territorios conocidos de la historia del arte o la cultura. Ese elemento que interrumpe el saber de una imagen conocida -interrumpiendo también su arcaica belleza- es particularmente la cobija. En esas imágenes la cobija funciona como un "signo secreto" pues está connotada por una específica situación cultural y política: la de ser un signo de muerte que ha devenido mortaja para la producción de fardos funerarios. En el contexto de estas imágenes la cobija deviene un síntoma de la muerte violenta. 
Son precisamente las materias, los objetos y las imágenes que documentan la agonía de los cuerpos, los elementos que -por los procedimientos de teatralidad fotográfica y montaje que hacen posible estas imágenes- interrumpen el curso de la visión, interrumpen un saber y se instalan como síntomas. Las fotografías exhibiendo fragmentos de cobijas con residuos de papel canela, las armas, los paquetes encintados, los cuerpos destrozados, son la constante de una sintomática aparición. Y pensar estas apariciones como síntomas nos lleva a reconocer que los síntomas han devenido relatos icónicos (Didi-Huberman, 2007, 141).

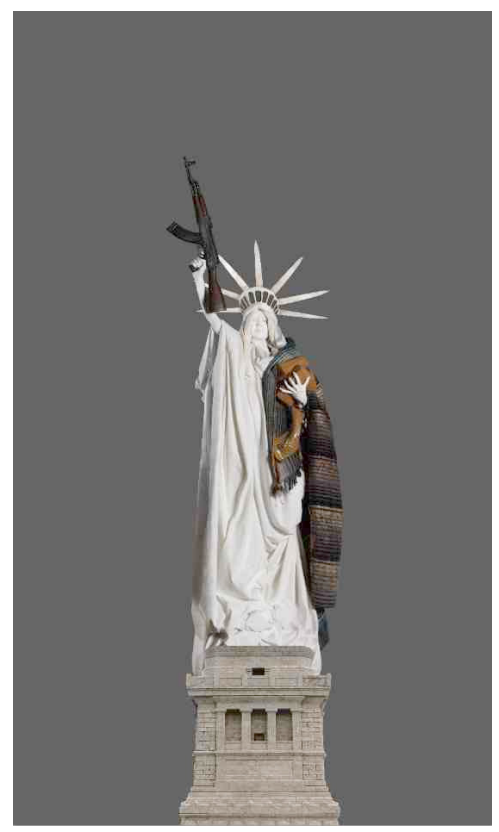

Imagen 7

La Estatua de La Libertad (2011-2012), de la serie La Rebelión de los iconos, de Rosa María Robles. Fotografía a color de Arturo Pérez Olivares, impresa en lienzo de 8.50 x 5.50 mts. Imagen cortesía de la artista.

En el campo de la imagen cultural y artística, el síntoma adviene como enigma o como un signo que puede resultar incomprensible pero que se impone visual y casi soberanamente. Quizás ello nos permita entender la singularidad de la cobija en determinado contexto, su voz fúnebre, su devenir icono. En la cobija, el cuerpo ausente ha encontrado un icono. Y esta suplantación de los cuerpos por vestigios expone otra dimensión de nuestro actual drama: la imposibilidad del duelo, la inconclusividad del dolor. Ese es el síntoma hecho icono en La Piedad de Rosa María Robles. 


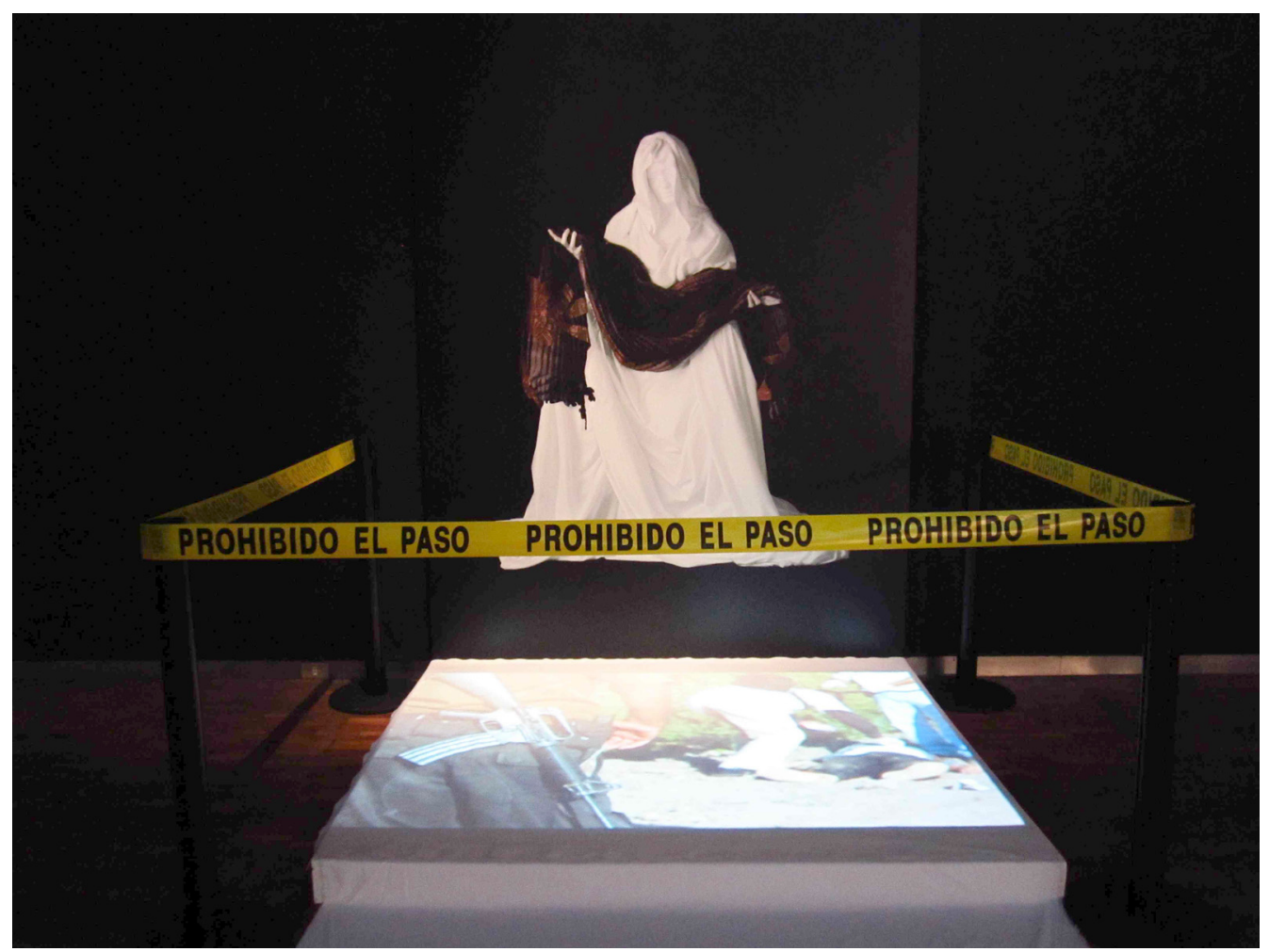

\section{Imagen 8}

La Piedad (2010), video instalación de Rosa María Robles, de la serie La Rebelión de los iconos. Fotografía de Jesús García, impresa sobre cintra. La instalación incluye una secuencia de imágenes documentales de la violencia en Sinaloa realizadas por Fernando Brito, que son proyectadas sobre una tela blanca. Fotografía tomada por Ileana Diéguez en la exposición Navajas (primera y segunda parte, 2007-2012) en el Centro de las Artes de Monterrey, marzo 2012.

En estos tiempos en que rondan los espectros sin sepultura, el paradigma gestual de la Pietá será el de sostener un vestigio como una nuevo imago para los cuerpos sin duelo. Las antiguas violencias sagradas están hoy diseminadas en los espacios de lo real, y su desmembramiento emblemático penetra los escenarios del arte.

\section{Bibliografía:}

Barthes, Roland. La cámara lúcida. Barcelona: Paidós, 1989.

Blair, Elsa. “Memoria y narrativa: La puesta del dolor en la escena pública”. Estudios Políticos, 21, Julio-dic 2002, pp.9-28.

. Muertes violentas. La Teatralización del exceso. Medellín: Universidad de Antioquia, 2005.

. “La política punitiva del cuerpo: economía del castigo o mecánica del sufrimiento en Colombia". Estudios Políticos 36, 2010, Instituto de Estudios Políticos, Universidad de Antioquia, pp. 39-66.

Clastres, Pierre. Arqueología de la violencia: la guerra en las sociedades primitivas. Trad. Luciano Padilla. México: F.C.E., 2004. 
Didi-Huberman, Georges. La invención de la histeria. Charcot y la iconografía fotográfica de la Salpêtriére. Madrid: Cátedra, 2007.

Adriana Hidalgo, 2008.

Ante el tiempo. Historia del arte y anacronismo de las imágenes. Buenos Aires: Warburg. Madrid: Abada, 2009.

. La imagen superviviente. Historia del arte y tiempo de los fantasmas según Aby . Arde la imagen. Oaxaca: Ve S.A de C.V y Fundación Televisa, 2012.

Durand, Gilbert. Las Estructuras Antropológicas del Imaginario: Introducción a la arquetipología general. México: F.C.E, 2004.

Foucault, Michel. Vigilar y castigar. Nacimiento de la prisión. México: Siglo XXI, 1976.

Mbembe, Achille. "Nécropolitique". Raisons politiques, n. 21, 2006, pp. 29-60. . Necropolitica. Trad. y ed. Elizabeth Falomir Archambault. Barcelona: Melusina, 2011.

Medina, Alvaro. El arte y la violencia colombiana en la segunda mitad del siglo XX. En: Arte y violencia en Colombia desde 1948. Bogotá: Museo de Arte Moderno de Bogotá-Grupo Editorial Norma, 1999. pp. 11-119.

Uribe, María Victoria. Matar, rematar y contramatar. Las masacres de la Violencia en el Tolima, 1948-1964. Bogotá: CINEP, 1990.

. Desde los márgenes de la cultura. Arte y violencia en Colombia desde 1948. Museo de Arte Moderno de Bogotá. Bogotá: Norma, 1999, pp. 277-286.

Bogotá: Norma, 2004.

. Antropología de la inhumanidad. Un ensayo interpretativo sobre el terror en Colombia.

Vera, Rodrigo. “Salvajismo primitivo". Semanario Proceso No. 1805, 5 de junio de 2011, pp. 6-12.

. “Decapitaciones rituales”. Semanario Proceso No. 1805, 5 de junio de 2011, pp. 8-9. 